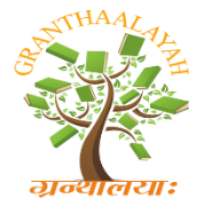

$$
\begin{gathered}
\text { INTERNATIONAL JOURNAL OF RESEARCH - } \\
\text { GRANTHAALAYAH } \\
\text { A knowledge Repository }
\end{gathered}
$$

Science

\title{
ANAL YSIS OF DIFFERENCES IN LEAD LEVELS (PB) IN BLOOD AND BONE DENSITY BEFORE AND AFTER CONSUMPTION OF GREEN COCONUT WATER AND MILK IN WORKERS AT THE " $\mathrm{X}$ " PAINTING BODY
}

\author{
Ismelda Iyou ${ }^{1}$, Nur Endah Wahyuningsih ${ }^{2}$, Sulistiyani ${ }^{2}$ \\ ${ }^{1}$ Graduate Master in Environmental Health, Diponegoro University, Semarang \\ ${ }^{2}$ Lecture Diponegoro University, Semarang
}

\begin{abstract}
Background: Lead $(\mathrm{Pb})$ becomes toxic to osteoblast cells and osteoclasts that affect the biology and deposition of bone mineral, thereby boosting the risk of osteoporosis. Green coconut water contains the highest tannins or antidotum (anti toxins), recommended for consumption for people exposed to heavy metals. While milk naturally contains essential nutrients to help control the regeneration of bone cells and strengthen bones.

Method: This research is a quasi experimental research using the one group pretest and posttest design. The number of research samples are 30 people who were given treatment of green coconut water and milk as much as $250 \mathrm{ml}$ alternately for 10 days

Result: Before the intervention of the lead category in the blood of the respondents exceeded the threshold value of NIOSH (10 $\mu \mathrm{g} / \mathrm{dL})$, ie 23 people averaged $14.04 \mu \mathrm{g} / \mathrm{dL}$ and after intervention decreased to 7 people on average $11.88 \mu \mathrm{g} / \mathrm{dL}$. The categories of osteopenia before intervention were 8 respondents averaging -0.59 and after intervention decreased ie 4 respondents average 1.90 .

Conclusion: There was a difference of $\mathrm{Pb}$ levels in blood before and after consumption of green coconut water and milk with $\mathrm{p}$ value $=0,001$ ( $\mathrm{p}$ value $<0,05)$. There was a difference of bone density before and after consumption of green coconut water and milk with $p$ value $=0,000$ ( $p$ value $<0,05)$.

Keywords: Blood Lead Level; Green Coconut Water; Milk; Bone Density.

Cite This Article: Ismelda Iyou, Nur Endah Wahyuningsih, and Sulistiyani. (2018). "ANALYSIS OF DIFFERENCES IN LEAD LEVELS (PB) IN BLOOD AND BONE DENSITY BEFORE AND AFTER CONSUMPTION OF GREEN COCONUT WATER AND MILK IN WORKERS AT THE "X" PAINTING BODY." International Journal of Research - Granthaalayah, 6(12), 90-96. https://doi.org/10.29121/granthaalayah.v6.i12.2018.1081.
\end{abstract}




\section{Introduction}

Lead is toxic to osteoblasts and osteoclasts which affect bone biology and deposition of minerals. Decreasing the amount and activation of osteoblastic cells caused by lead can weaken the skeletal structure so that it can increase the risk of osteoporosis.

It is recorded that more than 200 million people worldwide suffer from bone density. In the United States, cases of osteoporotic bone fractures reach more than 1.2 million annually. While in China according to the International Osteoporosis Foundation data, there has been an increase in osteoporosis by $300 \%$ in the last 30 years. In the UK every year it reaches $150,000-200,000$ people with osteoporosis have bone fractures. With the high number of cases of bone fractures in people with osteoporosis, the mortality rate will be high, which is more than $20 \%$ in the first year after the onset of a bone fracture.

In 2011 the results of an Egyptian study were conducted to see the relationship between lead exposure and the risk of various osteoporosis symptoms in male and female battery manufacturing workers. A total of 18 female workers and 24 male workers were selected with the same age range, hours of work per day, work history and weight. A total of 15 control groups were selected with no history of bone disease and blood lead concentration. It showed that both male and female workers had significant increases in lead concentration accompanied by osteoporosis when compared with controls.

The bodybuilding industry is a group of automotive industries that are engaged in making and assembling bus frames, completing their interiors, and selling them on behalf of their companies. This study took samples of painting workers because they were thought to be exposed to lead originating from frequently used paints. In the body, the painting process is done by spraying in a room like an oven with a temperature of around $60 \mathrm{oC}$, commonly called spray booth.

Secondary data are routine reports of air quality checks in the company environment carried out by the Integrated Laboratory Service (Sys Lab) as of May 31, 2016, obtained lead levels in air $<0.2 \mathrm{mg} / \mathrm{m} 3$. While the results of measurements of total dust and lead levels in the air of the working environment of the painting section carried out by the Central Java provincial environmental laboratory testing center for 8 hours were $1,727 \mathrm{mg} / \mathrm{m} 3$ and lead total dust of $0,00078 \mathrm{mg} / \mathrm{m} 3$.

The results of a preliminary study of bone health checks in the X carrosserie industry, out of 165 workers who examined bone health there were 112 workers affected by osteopenia. Based on this data the research sample taken to be used as respondents is as many as 30 people selected based on certain criteria.

Green coconut water is often used by people as traditional medicine and antidote to the body's toxins. Green coconut water, compared to other types of coconut contains a lot of tannin or antidotum (anti-poison) the highest so it is recommended to be consumed by people who are exposed to heavy metals that are quite high.

Milk is a source of calcium and phosphorus which is very important for bone formation. In order for the bones to be strong, you need adequate intake of nutrients, especially calcium. Someone 
who consumes low amounts of milk at the time of children, will prevent them from achieving maximum bone density (peak bone mass) as adults, so there will be a decrease in bone mass and can cause osteoporosis.

Based on the facts described above, this study aims to analyze the differences in Lead Levels in Blood and Bone Density Before and After Consumption of Milk Green Coconut Water in Workers Painting the "X" Body of Magelang Regency.

\section{Method}

This study was an experimental study with a type of quasi experiment with the design of the one group pre test and psot test. The initial test (pre test) was carried out by measuring the level of lead in the respondent's blood using the atomic absorbtion spectropometer (AAS) method and measuring bone density using a bone densimtometry tool and then intervening or treating it with administration of green coconut milk and milk in intervals for 10 days with a volume of $250 \mathrm{ml}$. After the intervention was carried out the measurement again (post test) again to find out the consequences of the treatment, so that the magnitude of the effects of the experiment can be known with certainty.

The population in this study were as many as 69 people who worked in the painting sector of the X Carrosserie in Magelang Regency. A sample of 30 people with purposive sampling method based on certain criteria. Variables in the study were age, years of service, length of work, use of PPE, consumption of green coconut water and consumption of milk. The controlling variables are cigarette consumption, caffeine consumption, drug use, calcium intake and exercise habits. Descriptive data analysis data, normality test data with Saphiro Wilk and hypothesis testing carried out by Wilcoxon test (Indonesia U.N.J.U \& Supeno)

\section{Results and Discussions}

\section{Characteristics of Respondents}

Age of respondents ranged from 22 - 56 years with a mean of 40.90 years. The working period of respondents is between 5-36 years with an average of 14.60 years. In detail, can be seen in table 1 below.

Respondents' habits about consumption of green coconut water, milk consumption, use of PPE, consumption of cigarettes, alcohol consumption, caffeine consumption, consumption of drugs, calcium intake, exercise habits can be seen in table 2.

Table 1: Characteristics of respondents numerical variables

\begin{tabular}{|l|c|c|c|c|c|}
\hline \multicolumn{1}{|c|}{ Variable } & Mean & Sd & Min & Max & N \\
\hline age & 40,90 & 8,543 & 22 & 56 & 30 \\
\hline Working Period (Year) & 14,60 & 9,084 & 5 & 36 & 30 \\
\hline
\end{tabular}

Table 1 shows that the characteristics of respondents are the average age of 40.90, standard deviation 8.543, minimum age 22 years and maximum age 56 years. The average tenure of 14.60 
standard deviations is 9,084 minimum work periods of 5 years and a maximum work period of 36 years.

Table 2: Characteristics of respondents categorical variables

\begin{tabular}{|l|l|c|}
\hline \multicolumn{1}{|c|}{ Variable (N=30) } & Frequency & $\mathbf{( \% )}$ \\
\hline Milk consumption category & & \\
1. Consuming & 30 & 100 \\
2. Not Consuming & 0 & 0 \\
\hline Coconut water consumption category & & \\
1. Consuming & 30 & 100 \\
2. Not Consuming & 0 & 0 \\
\hline Category of PPE Use & 9 & \\
1. Complete & 21 & 30 \\
2. Not complete & 26 & 70 \\
\hline Caffeine Consumption Category & 4 & 86,7 \\
1. Routine & & 13,3 \\
2. Not routine & 14 & \\
Drug Consumption Category & 16 & 46,7 \\
1. Routine & & 53,3 \\
2. Not routine & 13 & 43,3 \\
Calcium Intake Category & 17 & 56,7 \\
1. Routine & & \\
2. Not routine & 16 & 53,3 \\
Sports Habit Category & 14 & 46,7 \\
1. Routine &
\end{tabular}

Table 2 shows that as many as 30 respondents (100\%) consume green coconut water and milk, the category of mayoral majority use of PPE is 21 respondents (70\%), use of complete PPE 9 respondents $(30 \%)$. The alcohol consumption category of the majority of respondents who did not consume were as many as 17 respondents $(56.7 \%)$, the cigarette consumption category was the majority of respondents smoking as many as 24 respondents $(80 \%)$, the caffeine consumption category was the majority of respondents who consumed routinely as many as 26 respondents (86, $7 \%$ ), the consumption category of medicines for respondents who consume regularly is 14 respondents $(46.7 \%)$, the calcium intake category of respondents who consume regularly is as many as 17 respondents $(56.7 \%)$, the respondents' regular exercise habits category participating in the sport scheduled by the company, namely gymnastics and healthy walking every Friday which is 16 respondents $(53.3 \%)$.

Table 3: Results of Measurement of Lead Levels in Blood and Bone Density.

\begin{tabular}{|l|c|c|c|c|c|c|c|}
\hline \multicolumn{1}{|c|}{ Variable } & average & SD & Min. & Max. & N & \% & $\begin{array}{c}\text { NAB } \\
\text { NIOSH }\end{array}$ \\
\hline PB before & 14,04 & 3,52 & 9,83 & 27,08 & 30 & & $10 \mu \mathrm{g} / \mathrm{dL}$ \\
\hline PB after & 11,88 & 2,83 & 8,35 & 20,56 & 30 & & $10 \mu \mathrm{g} / \mathrm{dL}$ \\
\hline Bone density before & $-0,59$ & 0,64 & $-1,90$ & 0,70 & 30 & & \\
\hline Bone density after & $-0,15$ & 0,81 & $-1,70$ & 1 & 30 & & \\
\hline
\end{tabular}




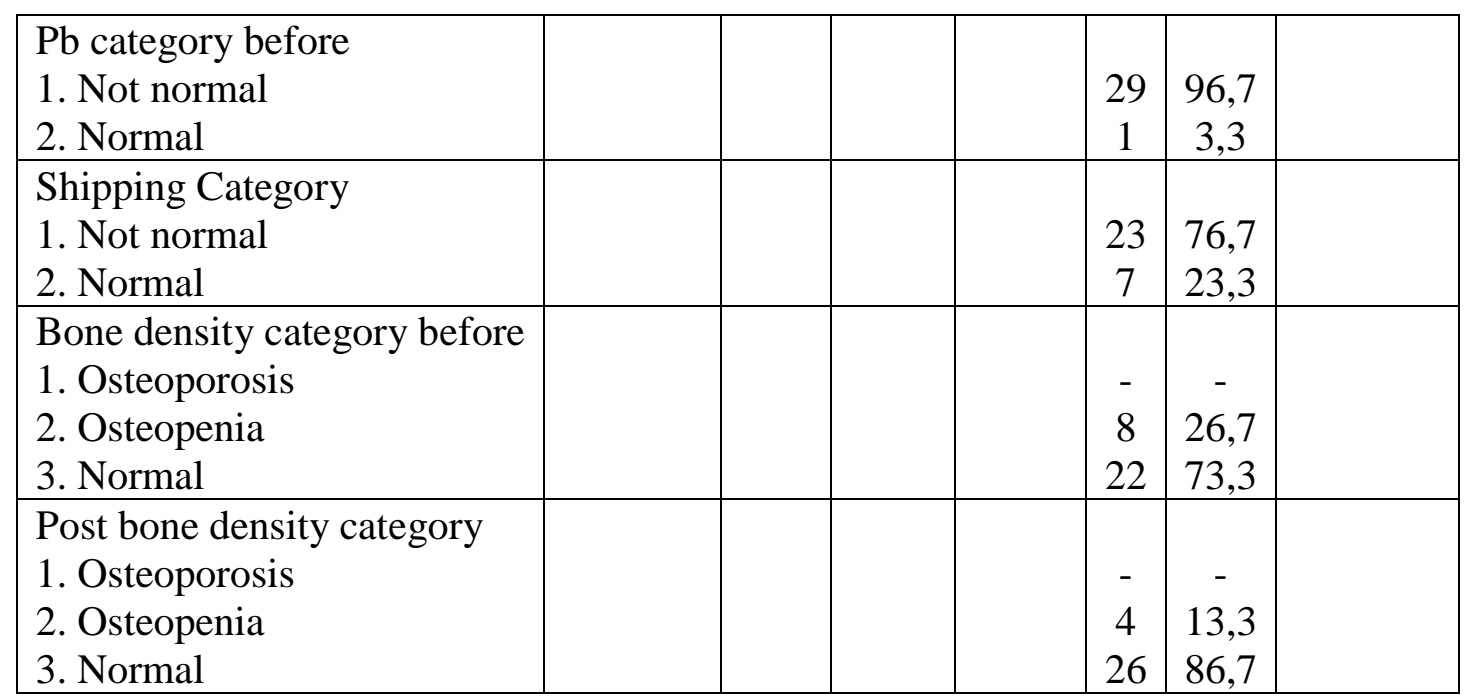

Table 3 shows that the lead levels in the blood of the respondents before being intervened in the abnormal category were 29 people $(96.7 \%$ ), averaging $14.04 \mu \mathrm{g} / \mathrm{dL}$, standard deviation of 3.52, minimum of 9.83, maximum of 27.08 and after the intervention was $11.88 \mu \mathrm{g} / \mathrm{dL}$, standard deviation 2.83, minimum 8.35 maximum 20.56. This, if based on the provisions of NIOSH (National Institute for Occupational Safety and Health), states that the limits of Blood Lead Levels (BLL) are $10 \mu \mathrm{g} / \mathrm{dL}$. After the intervention was decreased, there were 23 people $(76.7 \%)$, an average of $11.88 \mu \mathrm{g} / \mathrm{dL}$, a standard deviation of 2.83 minimum of 8.35 maximum of 20.56 .

Bone density is divided into 3 categories, namely Osteoporosis (DMT $=>-2.5$ ), osteopenia (DMT $=-1$ to -2.5$)$, normal (DMT $=<1)$. So based on bone density standards in the category of osteopenia before intervention, 8 respondents $(26.7 \%)$ had an average (-0.5), standard deviation (0.6), minimum (-1.90), maximum $(0,70)$ and after being intervened by 4 respondents $(13.3 \%)$ on average (-0.1), standard deviation (0.81), minimum (-1.70) maximum (1), while for the category of osteoporosis no respondent has it.

Table 4: Differences in Lead Levels in Blood and Bone Density

\begin{tabular}{|l|c|c|c|}
\hline Variabel & $\mathbf{Z}$ & $\mathbf{p}$ & Keterangan \\
\hline Kadar $\mathrm{Pb}$ & $-3,21$ & 0,001 & Ada perbedaan \\
\hline Densitas Tulang & $-4,233$ & 0,000 & Ada perbedaan \\
\hline
\end{tabular}

Table 4 shows the results of the Wilcoxon test that for Pb levels obtained significantly $\mathrm{p}=0.001$, for Bone Density $\mathrm{p}$ value $=0.00$ which means there are differences in $\mathrm{Pb}$ levels in the blood and bone density before and after consumption of green coconut water and milk.

The effect of heavy metal lead on bone cell function can last a lifetime. Lead is toxic to osteoblasts and osteoclasts which affect bone biology and deposition of minerals. Decreasing the amount and activation of osteoblastic cells caused by lead can weaken the skeletal structure so that it can increase the risk of osteoporosis.

Green coconut water (Cocus nucifera L) works as an antioxidant to ward off free radicals in the body depending on the type of antioxidant. Coconut water contains a chelating agent that functions 
to bind metals. Tanin molecules or ions found in green coconut water (Cocus nuciffera L) entering the body also circulate in the blood to bind or chew $\mathrm{Pb}$ metal ions found in the blood. The mechanism of chelating agent is the process of absorbing or replacing adsorbent compounds with chelating compounds. The chelinated tannins have the power to chelate $\mathrm{Pb}$ compounds by depositing $\mathrm{Pb}$ compounds so that they cannot be absorbed by the intestine and immediately removed so that the $\mathrm{Pb}$ compound becomes stable and safe in the body.

Green coconut water also contains calcium $(\mathrm{Ca})$ ions which also function to reduce blood levels of $\mathrm{Pb}$. The high calcium content in milk can help reduce lead levels in the blood and improve the regeneration of bone-forming cells. Calcium and lead are mutually competent so that it interferes with the absorption of lead $(\mathrm{Pb})$ into digestion. Calcium and lead metabolism is regulated by cholecalciferol endocrine system through 1,25-dihydroxivitamin $\mathrm{D}$ and calcium-binding protein by binding and precipitating $\mathrm{Pb}$ in the intestine so that absorption of lead in the intestine is disrupted. Competition between calcium and $\mathrm{Pb}$ in the intestine on the transport side, and the absorption mechanism by changing (altering) pleasure (avidity) of intestinal cells against $\mathrm{Pb}$, and by disrupting the affinity of the target tissue against the body.

The best source of calcium is also found in milk. Calcium serves to help the process of bone formation. Human bones experience a turning over that is continuous decay and formation. At a young age bone formation is more intense than its decay, whereas in old age the opposite is true. That is why in old age there is a process of losing bone mass (gradual lose of bone).

The importance of milk for health is not only for osteporosis problems. Milk also has the ability to bind heavy metals due to pollution. Thus, milk is useful to minimize exposure to heavy metals that enter the body.

\section{Conclusion}

This study concluded: 1). Before being intervened, respondents who had abnormal blood lead levels 29 people averaged $14.04 \mu \mathrm{g} / \mathrm{dL}$ and after intervention had decreased to 23 people on average $11.88 \mu \mathrm{g} / \mathrm{dL}$. 2). Before being intervened, respondents who suffered from osteopenia 8 averaged -0.59 and after intervention it decreased to 4 people on average -0.15 . 3). There were differences in $\mathrm{Pb}$ levels in the blood before and after consumption of green coconut milk and milk (p-value $=0.001) .4)$. There are differences in bone density levels before and after consumption of green coconut milk and milk ( $\mathrm{p}$-value $=0,000)$.

\section{References}

[1] Almatsier, Sunita, Prinsip Dasar Ilmu Gizi. PT. Gramedia Pustaka Utama. Jakarta. 2002

[2] Ballew, C. \& Bowman, B. Recommending Calcium to Reduce Lead Toxicity in Children; A Critical Review. Nutrition Review. Vol 159. 71-79. 2001

[3] Barlina, R Balitka. Kelapa Muda Bergizi Tinggi Menyehatkan dan Komersial. Warta Penelitian dan Pengembangan. Badan Penelitian dan Pengembangan Pertanian. 2009

[4] Bassem M. R., Nahed S. H and S W Aziz, Bone Mineral Density (BMD) and Osteoporosis risk factor in Egyptian male and female battery manufacturing workers. 2015. 
[5] Beier, E.E., Maher, J. R., Sheu T.J., Cory- Slechta, D. a., Berger, A.J, Zuscik, M.J, and Edward Puzas, J. Heavy metal lead exposure, osteoporotic-like phenotype in animal model, and depression of Wnt Signaling. Environment Health Perspective, 121 (1), 97-104. 2013.

[6] Candra Chesaria, et all, Perbedaan Kadar Timbal $(\mathrm{Pb})$ dalam Darah Sebelum dan Sesudah Konsumsi Air Kelapa Hijau (Cocos Nuciffera L) pada Pekerja Pengecatan di Industri Karoseri Semarang. 2016.

[7] Indonesia, U. N. J. U., \& Supeno, B. Development of Macromedia Flash Based Materials on Learning Social Science Knowledge in Class Xi Smk Islam Bustanul Ulum with Model Assure.

[8] Jhoni, Hubungan antara Kadar Timbal dalam Darah dengan Densitas Tulang pada Pekerja Peleburan Logam di Perkampungan Industri Kecil (PIK) Kebasen Kabupaten Tegal; 2016.

[9] Kalkwarf, Heidi J. Et all. Milk Intake during childhood and Adolescence, Adult Bone Density, and Osteoporotic Fractures in US Women. 2008

[10] Khomsan, Ali. Pangan dan Gizi untuk Kualitas Hidup. PT. Gramedia Widiaswarana. Jakarta. 2004

[11] Pusat Data dan Informasi Kementerian Kesehatan RI, Data dan Kondisi Penyakit Osteoporosis di Indonesia. 2015.

[12] Suheri, Teknik-teknik Menulis PTK Skripsi dan Tesis, Surabaya: Imtiyaz, 2017

*Corresponding author.

E-mail address: suheri.lpdp@ gmail.com 